\title{
PERAN SERTA WARGA MISKIN DALAM PROGRAM KEGIATAN PENANGGULANGAN KEMISKINAN DI KOTA SEMARANG TAHUN 2010
}

\author{
Tri Wahyu Rejekiningsih \\ Fakultas Ekonomika dan Bisnis Universitas Diponegoro Semarang \\ E-mail: triwahyu_r@yahoo.com
}

Diterima 9 Mei 2011/Disetujui 15 Juni 2011

\begin{abstract}
Most of the poor in Semarang who is married are about 69 percent with 3 persons of family dependents. 54 percent have their own house where 46 percent do not have it. The poor's main jobs are mostly as laborers. This is possible because the level of education are very low, there are about 59 percent have only primary school level. These condition will affect the productivity level of the poor so that they earn approximately about Rp 599.405,00 every month. The type of assistance the poor in Semarang received include: food (Raskin), health (Jamkesmas), house and road renovation (PNPM), and liquidity/ money (BLT). The periods of the assistance is once a month, for Raskin, whereas Jamkesmas provides a card for a free medical treatment.

The poor knowledge about the criteria of aid receiver is only 30 percent who knew, it means that there are 30 percent of poor people realize that they own the right to receive the aid. This causes the direct involvement level of the poor is very low, at only about 15 percent, while there are about 60 percent stated to not been involved and another 15 percent rarely involved. The form of the involvement are: participate to share or distribute, inform the other resident (notification), collect ID card and family member card of the resident who will get the aid. There are several types of assistance which is considered to accelerate resident alleviation from poverty: cheap food (Raskin), health (Jamkesmas), education (training skills), job opportunities and soft loans (capital bussiness).
\end{abstract}

Keywords: the poor, Raskin, Jamkesmas, Bantuan Langsung Tunai (BLT).

Pemerintah dalam upaya penanggulangan kemiskinan telah menggulirkan program yang telah ada sejak tahun1970-an yaitu melalui Rencana Pembangunan Lima Tahun (Repelita). Pada Repelita I - IV telah ditempuh secara reguler melalui program sektoral dan regional. Sedangkan pada Repelita V - VI, pemerintah melaksanakan program penanggulangan kemiskinan dengan strategi khusus menuntaskan masalah kesenjangan sosial-ekonomi. Jalur pembangunan ditempuh secara khusus dan mensinergikan program reguler sektoral dan regional yang ada dalam koordinasi Inpres Nomor 3 Tahun 1993 tentang Peningkatan Penanggulangan Kemiskinan yang akhirnya diwujudkan melalui program IDT (Inpres Desa Tertinggal). Upaya selama Repelita V - VI tersebut gagal akibat krisis ekonomi dan politik tahun 1997.

Untuk mengatasi dampak krisis yang lebih bu- ruk, pemerintah mengeluarkan program Jaring Pengaman Sosial (JPS) yang dikoordinasikan melalui Keppres Nomor 190 Tahun 1998 tentang Pembentukan Gugus Tugas Peningkatan Jaring Pengaman Sosial. Pelaksanaan berbagai kebijakan penanggulangan kemiskinan dan kendala pelaksanaannya selama 40 tahun terakhir meyakinkan pemerintah bahwa upaya penanggulangan kemiskinan dianggap belum mencapai harapan.

Melihat semakin urgennya permasalahan kemiskinan di Indonesia maka melalui Keputusan Presiden Nomor 124 Tahun 2001 junto Nomor 34 dan Nomor 8 Tahun 2002 maka dibentuklah Komite Penanggulangan Kemiskinan (KPK) yang berfungsi sebagai forum lintas pelaku dalam melakukan koordinasi perencanaan, pembinaan, pemantauan dan pelaporan seluruh upaya penanggulangan kemiskinan. Untuk 
lebih mempertajam keberadaan Komite Penanggulangan Kemiskinan maka pada tanggal 10 September 2005 dikeluarkan Peraturan Presiden Nomor 54 Tahun 2005 tentang Tim Koordinasi Penanggulangan Kemiskinan (TKPK). Keberadaan TKPK ini diharapkan melanjutkan dan mamantapkan hasil-hasil yang telah dicapai oleh KPK.

Tugas TKPK adalah melakukan langkah-langkah konkret untuk mempercepat pengurangan jumlah penduduk miskin di seluruh wilayah NKRI melalui koordinasi dan sinkronisasi penyusunan dan pelaksanaan penajaman kebijakan penanggulangan kemiskinan. TKPK juga memberikan kesempatan kepada masyarakat luas, dan berbagai dunia usaha untuk berperan serta aktif dalam menyukseskan program percepatan penanggulangan kemiskinan.

Program penanggulangan kemiskinan yang pernah dilaksanakan antara lain P4K (Proyek Peningkatan Pendapatan Petani dan Nelayan Kecil), KUBE (Kelompok Usaha Bersama), TPSP-KUD (Tempat Pelayanan Simpan Pinjam Koperasi Unit desa), UEDSP (Usaha Ekonomi Desa Simpan Pinjam), PKT (Pengembangan Kawasan Terpadu), IDT (Inpres Desa Tertinggal), P3DT (Pembangunan Prasarana Pendukung Desa Tertinggal), PPK (Program Pengembangan Kecamatan), P2KP (Program Penanggulangan Kemiskinan Perkotaan), PDMDKE (Pemberdayaan Daerah Mengatasi Dampak krisis Ekonomi), P2MPD (Proyek Pembangunan Masyarakat dan Pemerintah Daerah), dan program pembangunan sektoral telah berhasil memperkecil dampak krisis ekonomi dan mengurangi kemiskinan.

Program penanggulangan kemiskinan dilakukan juga oleh koordinasi Bank Indonesia melalui berbagai program keuangan mikro (microfinance) bersama bank-bank pembangunan daerah (BPD) dan bank-bank perkreditan rakyat (BPR) bekerja sama dengan lembaga-lembaga keuangan milik masyarakat seperti Lembaga Dana dan Kredit Perdesaan (LDKP) dan Kelompok Swadaya Masyarakat (KSM).

Selain itu beberapa lembaga keuangan milik pemerintah (Badan Usaha Milik Negara, BUMN) maupun milik swasta atas inisiatif sendiri menyelenggarakan pula program keuangan mikro dengan berbagai variasi dan kekhasan masing-masing lembaga keuangan itu. Demikian pula kalangan usaha nasional non-lembaga keuangan, baik milik pemerintah (BUMN) maupun milik swasta telah mengambil inisiatif melakukan upaya penanggulangan kemiskinan melalui beragam program, mulai dari bantuan sosial hingga bantuan ekonomi.

Mengentaskan kemiskinan merupakan upaya bersama yang dilakukan oleh pemerintah pusat (Pempus), pemerintah daerah (Pemda), dunia usaha, lembaga swadaya masyarakat, civitas akademika dan masyarakat.

Peranan pemda dalam upaya penanggulangan kemiskinan sangat strategis. Oleh karena itu TKPK Nasional mendorong upaya tersebut dapat diselesaikan secara mandiri oleh pemangku kepentingan di tingkat lokal (daerah). Penanggulangan kemiskinan merupakan tanggungjawab semua, supaya negeri kita terbebas dari kemiskinan. Langkah-langkah desentralisasi yang signifikan akan memberikan kesempatan yang luas untuk mendorong upaya-upaya tersebut.

Penanggulangan kemiskinan sebagai upaya peningkatan kesejahteraan rakyat memiliki lingkup permasalahannya semakin komplek, hal itu disebabkan karena pertambahan penduduk yang tidak terkontrol, ada pula kemiskinan baru yang disebabkan karena menjadi korban bencana alam, dan juga konflik antar kepentingan.

Permasalahan kemiskinan yang komplek tersebut dapat dirinci sebagai berikut :

a. Tingkat pendapatan rendah. Tingkat pendapatan yang rendah disebabkan oleh terjadinya ketidakadilan dan ketidakmerataan dalam distribusi penguasaan dan pengusahaan sumber daya yang tersedia.

b. Kualitas SDM rendah. Hal ini dikarenakan terbatasnya akses masyarakat miskin terhadap sumber permodalan, informasi, keahlian dan pasar.

c. Sistem Penanggulangan Kemiskinan dan perluasan kesempatan kerja yang belum optimal dan efektif.

d. Tingkat Keberdayaan dan kemandirian masyarakat masih rendah.

e. Tingkat kepedulian bersama terhadap masyarakat miskin masih rendah.

Berdasarkan permasalahan tersebut maka diperlukan upaya yang komprehensif menangani kemiskinan. Sehingga perlu dipadukan upaya-upaya yang parsial untuk mengefektifkan upaya penanggulangan kemiskinan baik yang ada di pusat kota maupun di daerah hingga pedesaan.

Penelitian ini bertujuan untuk: (a) Mengidentifikasi peran serta warga miskin atas program-program penanggulangan kemiskinan. (b) Mengidentifikasi 
program-program bantuan yang sebenarnya sangat dibutuhkan oleh warga misikin.

\section{TINJAUAN PUSTAKA}

\section{Konsep Kemiskinan}

Secara etimologis, "kemiskinan" berasal dari kata "miskin" yang artinya tidak berharta benda dan serba kekurangan. Departemen Sosial dan Badan Pusat Statistik mendefinisikan kemiskinan dari perspektif kebutuhan dasar. Kemiskinan didefinisikan sebagai ketidakmampuan individu dalam memenuhi kebutuhan dasar minimal untuk hidup layak (BPS dan Depsos, 2002). Lebih jauh disebutkan kemiskinan merupakan sebuah kondisi yang berada dibawah garis nilai standar kebutuhan minimum, baik untuk makanan dan non-makanan yang disebut garis kemiskinan (poverty line) atau batas kemiskinan (poverty treshold).

Konsep kemiskinan dapat dibedakan menjadi dua, yaitu kemiskinan absolut dan kemiskinan relatif. David Harry Penny (1990) mendefinisikan kemiskinan absolut dalam kaitannya dengan suatu sumber-sumber materi, yang dibawahnya tidak ada kemungkinan kehidupan berlanjut; dengan kata lain hal ini adalah tingkat kelaparan. Sedangkan kemiskinan relatif adalah perhitungan kemiskinan yang didasarkan pada proporsi distribusi pendapatan dalam suatu negara. World Bank (BPS, 2003) menyusun ukuran kemiskinan relatif yang sekaligus digunakan untuk mengukur tingkat pemerataan, yaitu dengan membagi penduduk menjadi tiga kelompok: (1) kelompok $40 \%$ penduduk berpendapatan rendah, $40 \%$ penduduk berpendapatan menengah dan $20 \%$ penduduk berpendapatan tinggi.

Ada banyak teori tentang kemiskinan, namun menurut Michael Sherraden (Arif, 2009) dapat dikelompokkan ke dalam dua kategori yang saling bertentangan dan satu kelompok teori yang tidak memihak (middle ground), yaitu teori yang memfokuskan pada tingkah laku individu (behavioral), teori yang mengarah pada struktur sosial, dan yang satu teori mengenai budaya miskin.

Menurutnya Teori yang memfokuskan pada tingkah laku individu merupakan teori tentang pilihan, harapan, sikap, motivasi dan kapital manusia (human capital). Teori ini disajikan dalam teori ekonomi neoklasik, yang berasumsi bahwa manusia bebas mengambil keputusan untuk dirinya sendiri dengan terse- dianya pilihan-pilihan. Perspektif ini sejalan dengan teori sosiologi fungsionalis, bahwa ketidaksetaraan itu tidak dapat dihindari dan diinginkan adalah keniscayaan dan penting bagi masyarakat secara keseluruhan. Teori perilaku individu meyakini bahwa sikap individu yang tidak produktif telah mengakibatkan lahirnya kemiskinan.

Teori Struktural yang bertolak belakang dengan teori perilaku memandang bahwa hambatan-hambatan struktural yang sistematik telah menciptakan ketidaksamaan dalam kesempatan, dan berkelanjutannya penindasan terhadap kelompok miskin oleh kelompok kapitalis. Variasi teori struktural ini terfokus pada topik seperti ras, gender atau ketidak sinambungan geografis dalam kaitannya atau dalam ketidakterkaitannya dengan ras.

Teori budaya miskin yang dikembangkan oleh Oscar Lewis dan Edward Banfield ini mengatakan bahwa gambaran budaya kelompok kelas bawah, khususnya pada orientasi untuk masa sekarang dan tidak adanya penundaan atas kepuasan, mengekalkan kemiskinan di kalangan mereka dari satu generasi ke generasi berikutnya.

Menurut Michael Sherraden bahwa dalam berbagai bentuk, teori budaya miskin ini berakar pada politik sayap kiri (Lewis) dan politik sayap kanan (Banfield). Dari sayap kiri, perspektif ini dikenal sebagai situasi miskin, yang mengindikasikan bahwa adanya disfungsi tingkah laku ternyata merupakan adaptasi fungsional terhadap keadaan-keadaan yang sulit (Arif, 2009). Dengan kata lain kelompok sayap kiri cenderung melihat budaya miskin sebagai sebuah akibat dari struktur sosial. Sebaliknya kelompok sayap kanan melihat tingkah laku dan budaya masyarakat kelas bawah yang mengakibatkan mereka menempati posisi di bawah dalam struktur sosial.

\section{Pendekatan Masalah Kemiskinan}

Ada dua pendekatan yang dapat digunakan dalam studi tentang kemiskinan, yaitu pendekatan obyektif dan pendekatan subyektif. Pendekatan obyektik yaitu pendekatan dengan menggunakan ukuran kemiskinan yang telah ditentukan oleh pihak lain terutama para ahli yang diukur dari tingkat kesejahteraan sosial sesuai dengan standart kehidupan. Pendekatan subyektif adalah pendekatan dengan menggunakan ukuran kemiskinan yang ditentukan oleh orang miskin itu sendiri yang diukur dari tingkat 
kesejahteraan sosial dari orang miskin dibandingkan dengan orang kaya yang ada dilingkungannya. Seperti diungkapkan oleh Joseph F. Stepanek (Arif, 2009) bahwa pendekatan subyektif menilai kemiskinan berdasarkan pendapat atau pandangan orang miskin sendiri.

Pendekatan kebutuhan dasar, melihat bahwa kemiskinan sebagai suatu ketidakmampuan (lack of capabilities) seseorang, keluarga dan masyarakat dalam memenuhi kebutuhan minimum, antara lain pangan, sandang, papan, pelayanan kesehatan, pendidikan, penyediaan air bersih dan sanitasi.

Sedangakan pendekatan pendapatan, melihat bahwa kemiskinan disebabkan oleh rendahnya penguasaan asset, dan alat-alat produktif seperti tanah dan lahan pertanian atau perkebunan, sehingga secara langsung mempengaruhi pendapatan seseorang dalam masyarakat. Pendekatan ini, menentukan secara rigid standar pendapatan seseorang di dalam masyarakat untuk membedakan kelas sosialnya. Demikian pula pendekatan kemampuan dasar yang menilai bahwa kemiskinan sebagai keterbatasan kemampuan dasar seperti kemampuan membaca dan menulis untuk menjalankan fungsi minimal dalam masyarakat.

Berbeda dengan pendekatan lainnya Pendekatan hak melihat bahwa kemiskinan didefinisikan sebagai kondisi di mana seseorang atau sekelompok orang, laki-laki dan perempuan, tidak terpenuhi hakhak dasarnya untuk mempertahankan dan mengembangkan kehidupan yang bermartabat. Hak-hak dasar yang diakui secara umum antara lain meliputi terpenuhinya kebutuhan pangan, kesehatan, pendidikan, pekerjaan, perumahan, air bersih, pertanahan, sumberdaya alam dan lingkungan hidup, rasa aman dari perlakukan atau ancaman tindak kekerasan dan hak untuk berpartisipasi dalam kehidupan sosial-politik, baik bagi perempuan maupun laki-laki.

\section{Kajian Literatur Tentang Kemiskinan}

\section{Ciri-Ciri Yang Melekat Pada Penduduk Miskin}

- Pendapatan masih rendah atau tidak berpendapatan

- Tidak memiliki pekerjaan tetap

- Pendidikan rendah bahkan tidak berpendidikan

- Tidak memiliki tempat tinggal

- Tidak terpenuhinya standar gizi minimal

\section{Pengertian, Ukuran dan Faktor Penyebab Kemiskinan}

Banyak pengertian yang diberikan para ahli mengenai kemiskinan. Ada yang memandang kemiskinan dari sisi material, atau non material, namun ada pula yang memandang dari kedua sisi tersebut. Ukuran kemiskinan pun menjadi sangat relatif sekali, seperti halnya pengertian tentang kemiskinan tersebut. Masing-masing orang memiliki ukuran yang berbeda. Sebagai contoh : ukuran miskin seorang petani akan sangat berbeda dengan ukuran miskin seorang pengusaha. Perbedaan ukuran ini terutama jika kemiskinan itu dipandang berdasarkan subyeknya. Akan tetapi, jika kemiskinan tersebut dipandang dari obyeknya, ukurannya menjadi relatif sama yaitu ukuran yang mendasarkan pada terpenuhinya kebutuhan dasar minimum manusia.

Abraham Maslow (1984) membagi kebutuhan manusia ke dalam 5 jenjang kebutuhan, yaitu :

a. Kebutuhan fisiologis seperti makan, minum, tempat berteduh, kesehatan, dan lain-lain.

b. Kebutuhan akan rasa aman dan tenteram, bebas dari rasa takut, jaminan keselamatan dan mendapat pekerjaan, serta adanya peraturan yang memberikan bimbingan dan pengarahan untuk bertindak.

c. Kebutuhan akan rasa memiliki, diakui dan diterima oleh lingkungannya, cinta-mencintai dan kebutuhan sosial lainnya.

d. Kebutuhan akan karya diri dan prestasi.

e. Kebutuhan akan aktualisasi diri.

Berdasarkan jenjang kebutuhan manusia tersebut, seseorang dapat dikatakan miskin jika kebutuhan fisiologi belum terpenuhi atau belum memenuhi standar minimum kebutuhan manusia.

Sajogyo (1977) mendefinisikan kemiskinan sebagai suatu tingkat kehidupan yang berada di bawah standar minimum yang ditetapkan berdasarkan atas kebutuhan pokok pangan yang membuat orang cukup bekerja dan hidup sehat, berdasarkan atas kebutuhan beras dan kebutuhan gizi. Pengukuran Sajogyo (1988) dalam membuat batasan kemiskinan di pedesaan didasarkan pada patokan cukup 1.900 kalori dan 40 gram protein per orang per hari. Ukuran tersebut dinyatakan dalam pengeluaran setara satuan kilogram beras per orang per tahun yaitu :
a. miskin sekali
$=$ kurang dari 240 kilogram
b. miskin
$=240$ sampai 320 kilogram
c. nyaris miskin
$=320$ sampai 480 kilogram. 


\section{METODE PENELITIAN}

\section{Definisi Operasional Variabel}

Berdasarkan perdefinisi bahwa kemiskinan ditentukan karena ketidakmampuan untuk mencukupi kebutuhan pokok minimum seperti pangan, sandang, kesehatan, perumahan dan pendidikan yang diperlukan untuk bisa hidup dan bekerja. Untuk memudahkan analisis, maka pemilihan warga miskin berdasarkan data warga miskin di setiap kelurahan yang telah menerima dan memanfaatkan bantuan dari program penanggulangan kemiskinan di Kota Semarang.

Adapun jenis bantuan dari program penanggulangan kemiskinan di Kota Semarang yang telah diterima dan dimanfaatkan oleh warga miskin adalah sebagai berikut: Askeskin, Jamkesmas, BLT, Raskin, P2KP-BKM, Konversi Minyak Tanah ke LPG, PNPM Mandiri, UED-SP, GPS dan Sembako (Bapermas Kota Semarang, 2009).

\section{Jenis Data}

Data yang digunakan dalam kajian ini meliputi data sekunder dan data primer. Data sekunder diperoleh dari Badan Pemberdayaan Masyarakat Perempuan Dan Keluarga Berencana Kota Semarang, BPS Provinsi Jawa Tengah, publikasi yang dikeluarkan lembaga-lembaga tertentu yang relevan serta kajian pustaka. Data sekunder yang diperlukan diantaranya seperti data profil warga miskin yang menerima dan memanfaatkan bantuan dari program penanggulangan kemiskinan Kota Semarang. Data sekunder diambil dari bahan pustaka yang berkaitan dengan kemiskinan.

Data primer diperoleh dari hasil survei dengan menggunakan kuesioner yang dilakukan terhadap warga miskin di seluruh kecamatan Kota Semarang (16 kecamatan) dengan kriteria Rawan Miskin (RM), Miskin (M) dan Sangat Miskin (SM).

\section{Jumlah Sampel}

Total populasi yang dijadikan obyek penelitian ini adalah sebanyak 111.557 KK Rumahtangga Miskin (Tabel 1). Untuk menentukan jumlah sampel perhitungannya berdasarkan populasi yang ada di setiap kecamatan. Penentuan jumlah sampel yang diambil menggunakan rumus Slovin, yaitu sebagai berikut: $\mathrm{n}=\mathrm{N} /\left(1+\mathrm{Ne}^{2}\right)$ dimana :

$\mathrm{n}=$ besaran sampel

$\mathrm{N}=$ besaran populasi

$\mathrm{e}=$ nilai kritis (batas ketelitian) yang diinginkan (persen kelonggaran ketidaktelitian karena kesalahan penarikan sampel) dan besarnya nilai tersebut adalah 10 persen. Nilai kritis 10 persen dipilih karena, merupakan batas nilai maksimal kelonggaran yang masih dapat ditoleransi.

Jadi besarnya sampel yang akan diambil sebagai contoh di kecamatan Semarang Tengah adalah sebesar : $\mathrm{n}=4.807 /\left(1+4.807(0,1)^{2}\right)=4.807 / 48,07=100 \mathrm{KK}$.

Sehingga masing-masing kecamatan di Kota Semarang akan diambil sampel sebanyak $100 \mathrm{KK}$. Secara keseluruhan jumlah sampel di Kota Semarang sebanyak $1600 \mathrm{KK}$ ( $16 \times 100$ ).

Berdasarkan data yang ada di Bapermas Kota Semarang, bahwa ada 3 (tiga) kriteria warga miskin (obyek penelitian) yaitu Rawan Miskin (RM), Miskin (M) dan Sangat Miskin (SM), maka pengambilan sampel dilakukan secara nonprobabilitas (pemilihan non random) dengan menggunakan metode purposive quota sampling. Purposive Quota Sampling adalah pengambilan sampel dari populasi berdasarkan suatu kriteria tertentu dan persentasi sampelnya sesuai dengan persentase jumlah populasinya (Jogiyanto, 2008). Dalam metode ini berdalih bahwa sampel harus mempunyai karakteristik yang dimiliki oleh populasinya. Artinya setiap kecamatan diambil sampel 100 KK dengan kriteria Rawan Miskin, Miskin dan Sangat Miskin.

Pada Tabel 2. ditunjukkan distribusi sampel yang diambil pada setiap kecamatan di Kota Semarang. Warga dengan kriteria sangat miskin yang ada di Kota Semarang diambil semuanya sebagai sampel dengan pertimbangan bahwa merekalah prioritas dari program pengentasan kemiskinan. Sementara bagi kecamatan yang tidak memiliki warga dengan kriteria sangat miskin, jumlah sampel tetap sebanyak $100 \mathrm{KK}$ dengan kriteria rawan miskin dan miskin. 
Tabel 1. Identifikasi Warga Miskin Di Kota Semarang Tahun 2009

\begin{tabular}{|c|c|c|c|c|c|c|c|c|c|}
\hline \multirow{2}{*}{ No } & \multirow{2}{*}{ Kecamatan } & \multicolumn{2}{|c|}{ Rawan Miskin } & \multicolumn{2}{|c|}{ Miskin } & \multicolumn{2}{|c|}{ Sangat Miskin } & \multicolumn{2}{|c|}{ Total } \\
\hline & & $\mathrm{KK}$ & Jiwa & $\mathrm{KK}$ & Jiwa & KK & Jiwa & KK & Jiwa \\
\hline 1. & Semarang Tengah & 2.706 & 9.045 & 2.097 & 7.091 & 4 & 21 & 4.807 & 16.157 \\
\hline 2. & Semarang Utara & 8.608 & 30.679 & 4.654 & 16.913 & 12 & 36 & 13.274 & 47.628 \\
\hline 3. & Semarang Timur & 5.012 & 17.575 & 1.453 & 4.912 & 1 & 5 & 6.466 & 22.492 \\
\hline 4. & Gayamsari & 4.884 & 17.792 & 1.741 & 6.634 & 6 & 20 & 6.631 & 24.446 \\
\hline 5. & Genuk & 6.352 & 25.432 & 1.281 & 4.975 & 0 & 0 & 7.633 & 30.407 \\
\hline 6. & Pedurungan & 5.156 & 19.609 & 1.642 & 6.258 & 0 & 0 & 6.798 & 25.877 \\
\hline 7. & Semarang Selatan & 2.713 & 9.139 & 1.739 & 5.725 & 2 & 6 & 4.454 & 14.870 \\
\hline 8. & Candisari & 4.179 & 14.616 & 1.271 & 4.479 & 1 & 2 & 5.451 & 19.097 \\
\hline 9. & Gajahmungkur & 1.964 & 6.808 & 1.067 & 3.666 & 0 & 0 & 3.031 & 10.474 \\
\hline 10. & Tembalang & 7.236 & 25.569 & 4.018 & 14.377 & 11 & 41 & 11.265 & 39.987 \\
\hline 11. & Banyumanik & 4.303 & 15.513 & 1.052 & 3.802 & 0 & 0 & 5.355 & 19.315 \\
\hline 12. & Gunungpati & 4.217 & 14.361 & 1.961 & 6.617 & 4 & 14 & 6.182 & 20.992 \\
\hline 13. & Semarang Barat & 9.515 & 33.755 & 4.526 & 16.499 & 4 & 12 & 14.045 & 50.266 \\
\hline 14. & Mijen & 3.104 & 10.312 & 1.830 & 5.860 & 2 & 9 & 4.936 & 16.181 \\
\hline 15. & Ngaliyan & 4.788 & 16.801 & 2.462 & 8.573 & 9 & 30 & 7.259 & 25.404 \\
\hline 16. & Tugu & 2.874 & 10.379 & 1.095 & 4.028 & 1 & 6 & 3.970 & 14.413 \\
\hline & & 77.611 & 277.385 & 33.889 & 120.419 & 57 & 202 & 111.557 & 398.006 \\
\hline
\end{tabular}

Sumber : Bapermas Kota Semarang, 2010.

Tabel 2. Jumlah Sampel Menurut Kategori Miskin Pada Setiap Kecamatan di Kota Semarang Tahun 2010

\begin{tabular}{|l|l|r|r|r|r|r|r|r|r|}
\hline \multirow{2}{*}{ No } & \multirow{2}{*}{ Kecamatan } & \multicolumn{2}{|c|}{ Rawan Miskin } & \multicolumn{2}{|c|}{ Miskin } & \multicolumn{2}{|c|}{ Sangat Miskin } & \multicolumn{2}{c|}{ Total } \\
\cline { 3 - 9 } & & KK & Smpl & KK & Smpl & KK & Smpl & KK & Sampel \\
\hline 1. & Semarang Tengah & 2.706 & 32 & 2.097 & 64 & 4 & 4 & 4.807 & 100 \\
2. & Semarang Utara & 8.608 & 29 & 4.654 & 59 & 12 & 12 & 13.274 & 100 \\
3. & Semarang Timur & 5.012 & 33 & 1.453 & 66 & 1 & 1 & 6.466 & 100 \\
4. & Gayamsari & 4.884 & 31 & 1.741 & 63 & 6 & 6 & 6.631 & 100 \\
5. & Genuk & 6.352 & 33 & 1.281 & 67 & 0 & 0 & 7.633 & 100 \\
6. & Pedurungan & 5.156 & 33 & 1.642 & 67 & 0 & 0 & 6.798 & 100 \\
7. & Semarang Selatan & 2.713 & 33 & 1.739 & 65 & 2 & 2 & 4.454 & 100 \\
8. & Candisari & 4.179 & 33 & 1.271 & 66 & 1 & 1 & 5.451 & 100 \\
9. & Gajahmungkur & 1.964 & 33 & 1.067 & 67 & 0 & 0 & 3.031 & 100 \\
10. & Tembalang & 7.236 & 30 & 4.018 & 59 & 11 & 11 & 11.265 & 100 \\
11. & Banyumanik & 4.303 & 33 & 1.052 & 67 & 0 & 0 & 5.355 & 100 \\
12. & Gunungpati & 4.217 & 32 & 1.961 & 64 & 4 & 4 & 6.182 & 100 \\
13. & Semarang Barat & 9.515 & 32 & 4.526 & 64 & 4 & 4 & 14.045 & 100 \\
14. & Mijen & 3.104 & 33 & 1.830 & 65 & 2 & 2 & 4.936 & 100 \\
15. & Ngaliyan & 4.788 & 30 & 2.462 & 61 & 9 & 9 & 7.259 & 100 \\
16. & Tugu & 2.874 & 33 & 1.095 & 66 & 1 & 1 & 3.970 & 100 \\
\hline & & 77.611 & 514 & 33.889 & 1.029 & 57 & 57 & 111.557 & 1.600 \\
\hline
\end{tabular}

Sumber : Hasil perhitungan dengan rumus Slovin.

\section{Metode Analisis}

Data yang diperoleh atas dasar pengisian kuesioner dari sampel warga miskin di Kota Semarang yang terdistribusi pada 16 kecamatan akan disajikan dalam bentuk persentase dan tabulasi, yang pada akhirnya dianalisis secara deskriptif.

\section{HASIL DAN PEMBAHASAN}

\section{Hasil Pendataan}

Dari jumlah sampel yang telah direncanakan sebanyak 1600 responden ternyata ada beberapa kendala, sehingga sampel yang bisa terambil sebanyak 1561 responden. Oleh karena itu jumlah warga miskin yang dijadikan sampel penelitian dengan rincian sebagai berikut :

\begin{tabular}{|l|l|l|l|l|}
\hline & RM & M & SM & Jumlah \\
\hline Sampel & 503 & 999 & 59 & 1561 \\
\hline
\end{tabular}

\section{Pendidikan Warga Miskin}

Dari tabulasi data primer maka diketahui bah- 
wa dominansi pendidikan warga miskin masih di tingkat sekolah dasar. Warga miskin yang berpendidikan maksimal tamat sekolah dasar ada 934 responden $(59,83 \%)$, tamat SLTP $=284$ responden $(18,19 \%)$, tamat SLTA $=326$ responden $(20,88 \%)$ dan tamat $\mathrm{D} 3 / \mathrm{S} 1=17$ responden $(1,09 \%)$. Distribusi persentase tersebut hampir merata pada setiap kecamatan di Kota Semarang.

\section{Pekerjaan dan Penghasilan Warga Miskin}

Jenis pekerjaan yang banyak digeluti oleh warga miskin ada empat (4) yaitu sebagai : buruh (63\%), pedagang (33\%), karyawan (3\%) dan pengangguran (1\%). Penghasilan warga miskin, rata-rata setiap KK per bulan di masing-masing kecamatan sebesar Rp $599.600,0$

\section{Jumlah Tanggungan Dan Status Kepemilikian Rumah}

Setiap KK warga miskin menanggung anggota keluarga sebanyak antara 1 orang s/d 6 orang. Secara rata-rata yang ditanggung adalah sebanyak 3 orang oleh setiap KK warga miskin.

Ada sekitar $45,16 \%$ warga miskin tidak memiliki sendiri tempat tinggalnya. Distribusi status kepemilikan tempat tinggal bagi warga miskin yaitu : milik sendiri ada $856 \mathrm{KK}(54,84 \%)$, milik orangtua/mertua ada $437 \mathrm{KK}$ (27,99\%), kontrak/sewa ada $153 \mathrm{KK}(9,80 \%)$, dan milik teman/saudara ada 115 KK $(7,37 \%)$.

\section{Penerimaan Bantuan}

Pemberian bantuan yang diserahkan kepada warga miskin pada setiap Kelurahan di Kota Semarang seringnya diberikan sebulan sekali. Meskipun demikian masih diketemukan ada sekitar $80 \mathrm{KK}$ warga miskin $(5,12 \%)$ yang mengaku tidak pernah menerima bantuan jenis apapun. Adapun jumlah warga miskin yang mengaku jarang menerima bantuan ada sekitar $794 \mathrm{KK}$ (50,86\%), sedangkan yang mengaku sering menerima bantuan ada sekitar $687 \mathrm{KK}(44,02 \%)$.

Jenis bantuan yang pernah diterima warga miskin meliputi : raskin, jamkesmas/jamkesmaskot, BLT, Gas, dan Pembangunan MCK

\section{Pengetahuan Kriteria Penerima Bantuan}

Setiap jenis bantuan dalam pendistribusiannya ke warga miskin memiliki kriteria-kriteria tertentu. Ternyata dari survei diketahui bahwa tidak semua warga miskin mengetahui tentang kriteria penerima bantuan. Ada $473 \mathrm{KK}$ warga miskin $(30,30 \%)$ yang tidak mengetahui tentang kriteria penerima bantuan, 612 KK $(39,21 \%)$ mengetahui tapi samar-samar dan 476 KK $(30,49 \%)$ yang tahu akan kriteria penerima bantuan. Sehingga hasil tersebut menunjukkan bahwa, ada sekitar 30,30\% warga miskin yang tidak tahu mengapa dirinya menerima bantuan.

\section{Keterlibatan Dalam Pembagian Bantuan}

Dalam proses pembagian bantuan pihak terkait hampir bisa dikatakan tidak melibatkan warga miskin yang akan menerima bantuannya. Berdasarkan survei diketahui bahwa warga miskin yang tidak pernah dilibatkan dalam pembagian bantuan sebanyak $954 \mathrm{KK}$ $(61,11 \%)$, jarang terlibat ada $364 \mathrm{KK}(23,32 \%)$ dan yang sering dilibatkan hanya $243 \mathrm{KK}(15,57 \%)$.

Sedikitnya warga miskin yang terlibat dalam proses pemberian bantuan, ini terkait dengan ketidaktahuannya tentang kriteria penerima bantuan. Dalam hal ini warga miskin hanya pasif di rumah lalu diberitahu akan menerima bantuan. Adapun bentuk keterlibatan warga miskin yaitu membantu membagikan kartu raskin kepada warga yang akan menerima bantuan.

\section{Keterlibatan Masyarakat Sekitar}

Partisipasi masyarakat sekitar dalam keterlibatannya pada proses pembagian bantuan kepada warga miskin, teridentifikasi sebagai berikut :

- Tidak ada $=330(21,14 \%)$

- Jarang = $646(41,38 \%)$

- Banyak = $585(37,48 \%)$

Dapat dikatakan bahwa masyarakat sekitar (bukan penerima bantuan) juga turut membantu proses distribusi bantuan kepada warga miskin $(78,86 \%)$.

\section{Tujuan Jenis Bantuan}

Setiap jenis bantuan yang disalurkan kepada warga miskin memiliki tujuan. Namun tidak semua warga miskin tahu akan tujuan masing-masing bantuan yang diterimanya. Dari hasil survei diketahui pengetahuan warga miskin tentang tujuan dari bantuan yang diterimanya adalah sebagai berikut :

$\begin{array}{ll}\text { - } \text { Tidak tahu } & =367(23,51 \%) \\ \text { - } T a h u \text { sedikit } & =720(46,12 \%) \\ \text { - } \text { Tahu } & =474(30,37 \%)\end{array}$

Artinya bahwa warga miskin banyak yang tahu ( 76,49\%) akan tujuan dari setiap jenis bantuan yang diterimanya. Pengetahuana akan tujuan tersebut diperoleh warga miskin dari Ketua/Pengurus RT.

Secara keseluruhan tujuan dari pemberian ban- 
tuan adalah untuk meringankan beban ekonomi. Adapun bentuk bantuan meliputi :

- raskin = harga beras murah

- jamkesmas $=$ berobat gratis

- BLT = uang tunai

- Gas = mengganti minyak tanah.

\section{Pendapat Tentang Bantuan}

Hasil dengar pendapat atas bantuan yang diterimanya, ada tiga jawaban warga miskin dalam menanggapinya yaitu :

- Senang/suka $=1465(93,85 \%)$

- Biasa saja $=85(5,45 \%)$

- Tidak senang/suka $=11(0,70 \%)$

Sebagian besar $(93,85 \%)$ warga miskin merasa senang ketika menerima bantuan. Alasannya bahwa bantuan yang diterima sangat bermanfaat bagi keluargnya. Selain itu, dengan pembagian bantuan tersebut, warga miskin juga merasa diperhatikan oleh pemerintah, meskipun ada sekitar $0,70 \%$ warga miskin yang merasa tidak senang ketika menerima bantuan.

\section{Jenis Bantuan yang Diharapkan}

Menurut pendapat warga miskin, sebenarnya jenis bantuan yang lebih diinginkannya adalah bantuan yang berupa :

- modal usaha

- beras murah (raskin)

- uang (BLT)

- pelatihan ketrampilan

Berbeda dengan pendapat para kepala kelurahan yang prihatin melihat bahwa jumlah angka kemiskinan yang cenderung bertambah di Kota Semarang. Menurut para kepala kelurahan bahwa jenis bantuan untuk mengentaskan kemiskinan adalah :

- modal usaha

- ketrampilan

- kesempatan/lapangan kerja

- kesehatan

- pendidikan

- bibit pertanian

- air bersih

\section{Pembahasan}

Sebagian besar warga miskin di Kota Semarang berstatus kawin ada sekitar 69 persen dengan jumlah tanggungan rata-rata 3 jiwa dan memiliki rumah sendiri ada 54 persen, maka 46 persen tidak memiliki tempat tinggal sendiri. Pekerjaan pokok warga miskin sebagian besar adalah sebagai buruh atau serabutan. Hal ini memungkinkan karena tingkat pendidikan juga sangat rendah yaitu ada sekitar 59 persen berpendidikan Sekolah dasar (SD). Kondisi ini akan berpengaruh kepada tingkat produktivitas warga miskin sehingga rendah dan rata-rata penghasilnnya sebesar kurang lebih Rp 599.405,00 per bulan.

Jenis bantuan yang telah diterima warga miskin di Kota Semarang meliputi : pangan (Raskin), kesehatan (Jamkesmas), renovasi rumah \& jalan (PNPM) dan likuiditas/uang (BLT). Periode pemberian bantuan seringnya setiap bulan sekali, misalnya Raskin, sedangkan jamkesmas berujud kartu untuk berobat gratis.

Pengetahuan warga miskin tentang kriteria penerima bantuan ternyata hanya 30 persen yang tahu, artinya ada 30 persen warga miskin yang menyadari bahwa dirinya miskin yang berhak memperoleh bantuan. Sehingga hal ini menyebabkan tingkat keterlibatan warga miskin secara langsung terhadap jenis bantuan sangat rendah, yaitu hanya sekitar 15 persen, sedangkan ada 60 persen menyatakan tidak pernah terlibat dan 15 persennya jarang terlibat. Adapun bentuk keterlibatan warga miskin terhadap jenis bantuan meliputi: ikut membagikan/mendistribusikan, memberitahukan ke warga lain (woro-woro), mengumpulkan KTP dan KK warga yang akan memperoleh bantuan.

Warga miskin yang mengetahui tentang tujuan dari setiap jenis bantuan yang diterimanya ada sekitar 75 persen, sedangkan 25 persenya tidak mengetahuinya. Pengetahuan tersebut diperoleh warga dari Ketua/Pengurus RT/RW dan teman/saudara/tetangga. Menurut yang diketahui oleh warga miskin tentang tujuan bantuan, yaitu bahwa raskin untuk meringankan beban sehari-hari dengan beras murah, jamkesmas untuk berobat gratis dengan kartu sehat, dan Bantuan Langsung Tunai (BLT) untuk membantu ekonomi warga dengan uang tunai. Ini didukung dengan adanya pemberitahuan terlebih dahulu oleh RT/RW/Kelurahan kepada warga miskin yang akan menerima bantuan. Penerimaan warga atas bantuan sangat bagus yaitu bahwa hampir 90 persen menyatakan senang menerima bantuan, karena dengan adanya bantuan dinilai sangat bermanfaat baik bagi dirinya maupun keluarganya. 


\section{KESIMPULAN DAN SARAN}

\section{Kesimpulan}

a. Bahwa dalam proses pemberian bantuan banyak warga miskin yang tidak terlibat yaitu mencapai 92 persen, sehingga mereka hanya berperan pasif sebagai penerima bantuan saja.

b. Ada sekitar 70 persen warga miskin tahu tentang kriteria penerima bantuan, ini diharapkan akan sangat membantu mengurangi jumlah orang miskin. Harapannya dengan tahunya kriteria penerima bantuan akan membuat warga miskin menjadi

\section{DAFTAR PUSTAKA}

Anto Dajan, 1973, Pengantar Metode Statistik, Jilid II, LP3ES, Jakarta.

Arif Noer Hakim, 2009, Teori dan Pendekatan Masalah Kemiskinan, 20 Agustus.

Bayo Ala, A, 1981, Strategi Anti Kemiskinan Lima Tahap, Analisa No.9, Tahun X, September 1981, CSIS, Jakarta.

BPS, 2007, Analisis dan Penghitungan Tingkat Kemiskinan Tahun 2007, Jakarta

Koentjaraningrat, 1983, Kebudayaan, Mentalitet dan Pembangunan, PT.Gramedia, Jakarta

Muslow, A.H, 1984, Motivasi dan Kepribadian, PT. Pustaka Binama Pressindo, Jakarta.

Mudrajat Kuncoro, 2000, Ekonomi Pembangunan, Teori, Masalah dan Kebijakan, BPFE-UGM, Jogjakarta. malu sehingga akan mendorong mereka untuk berjuang supaya tidak masuk kriteria penerima bantuan lagi.

\section{Saran}

Secara umum untuk mempercepat bisa mengentaskan warga dari kondisi kemiskinan, ada beberapa jenis bantuan yang dapat diberikan kepada warga miskin, yaitu Pangan murah (Raskin), kesehatan (jamkesmas), pendidikan (pelatihan/ketrampilan), kesempatan kerja dan pinjaman lunak (modal usaha).

Sajogyo, 1977, Garis Kemiskinan dan Kebutuhan Pokok, LPSP-IPB, Bogor

Sajogyo, Lala M Kolopaking, dan Sumardjo, 1983, Profil Rumahtangga Pertanian Tanaman Pangan, Perikanan Darat dan Perariran Umum dan Peternakan. Sensus Pertanian 1983, BPS, Jakarta.

Soetandyo Wignjosoebroto, 1995, Kemiskinan Struktural : Masalah dan Kebijakan,

Tjiptoherijanto, Prijono dan Sutyastie Soemitro, 1997, Sumber Daya Manusia Dalam Pembangunan Nasional, Jakarta.

Tjiptoherijanto, Prijono dan Sutyastie Soemitro, 1998, Pemberdayaan Penduduk dan Peningkatan Kualitas Sumber Daya Manusia, Jakarta. 